\title{
Precious plants
}

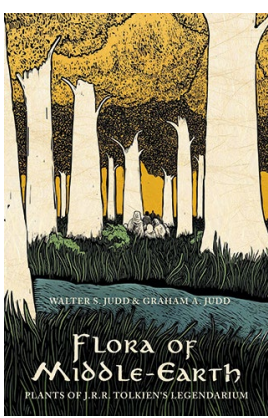

themselves. So often in books and films, plants are evoked as background - they are just there to lean against, crash into, or shelter under - while animals tend to take more central roles. Despite the fact that plants are essential for our daily lives in a myriad of ways, human beings seem to suffer from a disease that has been called by many plant blindness (although it was clearly not one of Tolkien's problems). From food to fibre, to the very oxygen we breathe, all life depends on plants, but they are as good as invisible in many walks of life. Even conservation focuses the warm and fuzzy or feathered, there is something about vertebrate eyes I think. So wasn't it clever of Tolkien to create the Ents talking, walking, sensible trees with eyes that readers of the books and watchers of the films (not that he knew about the films at the time) can relate to.

Although the book is a 'proper' flora, with all the scientific parts such a work contains, the organization is not by the plant families as taught in introductory plant taxonomy classes. The plants here are organized by common name, making this book immediately accessible to a reader of Tolkien - clearly a target audience. To me this is one of the joys of the book. It illustrates so clearly why scientific works must first think of the audience, and then organize the content. If your audience is other scientists, then of course a taxonomic or phylogenetic arrangement is the one to go for. But if your audience is bird-watchers or Tolkien-readers or schoolchildren or local communities, then thinking carefully about how best to present the information to make entry easy and enjoyable is paramount. I love the way the authors of this flora have presented the plants, those that belong to currently recognized plant families as well as the imaginary plants of Middle Earth, such as the White Tree of Gondor, Teleperion and Laurelin. Although Tolkien himself described these trees well, Judd and Judd bring them alive in a botanical sense - the details of morphology and possible affinities spring from the page.

The world of Middle Earth was apparently meant to be that of rural England - the hobbits were gardeners and well-versed in plant lore, just like English village folk of Tolkien's time. Judd and Judd maintain that Tolkien explicitly did not include plants that had been introduced to Europe from the Americas, such as tobacco or tomatoes, or from Asia, in Gandalf's cup of tea or in the silk in Bilbo's waistcoat spun from the silk of caterpillars that feed on the leaves of mulberry trees. Tolkien's flora was not perfect though, he included 'pipe-weed', clearly tobacco, and 'taters', clearly potatoes, along with some other plants that were introduced to England post-colonization of the Americas. The authors speculate, somewhat tongue in cheek I suspect, that there may have been two introductions of potatoes to England, one in the time of Middle Earth, and one in our own. But in a way, that doesn't matter - our world has been globalized for a long, long time - the origins of some plants with worldwide distributions are still not well-known. Just what is natural is hotly debated. Even the vast forests of the Amazon, thought by many to be pristine and untouched, have been extensively managed by people since our species' arrival on the South American continent. The human footprint is vast, and it is worldwide, even on Antarctica seeds brought inadvertently by travellers are becoming established.

But management and destruction are two very different things, clearly one of the motivations for Flora of Middle Earth. Just as the evil forces of Mordor destroyed forests, decimating the Ents and their flocks, Judd and Judd remind us that we are doing the same thing to our planet right now. This book is a very creative way to help reduce plant blindness, both in Tolkien fans and for those studying plants more generally. The more we see plants as integral to our daily lives and not just a background to be disregarded at will, the better our world will be for us and for our descendants. Flora of Middle Earth will delight Tolkien enthusiasts - of whom there are many - with its erudite exploration of the natural history of Middle Earth, but it also has much to offer for botanists, especially those thinking about how to present plants of our green and diverse planet to new audiences. Appreciation of the plants of our own world is urgent if we are to eventually profit from plant diversity in the future. My hope is that this book will engender the love of those plants in more people who, up to now, may not have seen them at all.

Reviewed by Sandra Knapp Sandra Knapp, Department of Life Sciences, Natural History Museum, London, UK. e-mail:s.knapp@nhm.ac.uk

Published online: 7 November 2017 https://doi.org/10.1038/s41477-017-0054-0 